\title{
Physico-Chemical and Bacteriological Characteristics of Hand-Dug Wells and Boreholes Water Quality of the Vina Division, Cameroon
}

\author{
Simeon Pierre Chegaing Fodouop ${ }^{1,3}$, *, Steve Francky Sohanang Nodem ${ }^{2}$, Larissa Nsuh ${ }^{1}$, \\ Patrice Kamga Bogne ${ }^{2}$, Guide Lonang Djomsi ${ }^{1}$, Hierry Marcel Ntsamo Beumo ${ }^{2}$, \\ Didiane Yemele Mefokou ${ }^{1,3}$ \\ ${ }^{1}$ Department of Biomedical Sciences, Faculty of Sciences, University of Ngaoundere, Ngaoundéré, Cameroon \\ ${ }^{2}$ Department of Food Science and Nutrition, National Advanced School of Agro-Industrial Sciences, University of Ngaoundere, Ngaoundere, \\ Cameroon \\ ${ }^{3}$ Sunshine Laboratory of Research and Biomedical Analysis, Ngaoundere, Cameroon
}

Email address:

saafodouop@yahoo.fr (S. P. C. Fodouop)

To cite this article:

Simeon Pierre Chegaing Fodouop, Steve Francky Sohanang Nodem, Larissa Nsuh, Patrice Kamga Bogne, Guide Lonang Djomsi, Hierry Marcel Ntsamo Beumo, Didiane Yemele Mefokou. Physico-Chemical and Bacteriological Characteristics of Hand-Dug Wells and Boreholes Water Quality of the Vina Division, Cameroon. Central African Journal of Public Health. Vol. 7, No. 3, 2021, pp. 136-143.

doi: 10.11648/j.cajph.20210703.17

Received: March 10, 2021; Accepted: March 27, 2021; Published: June 15, 2021

\begin{abstract}
Background: Limited access to safe drinking water and lack of information on water quality in the sub-urban and rural regions of Cameroon has contributed to regular outbreaks of diarrheal diseases. Objectives: The aim of this study was to assess the bacteriological quality of drinking water in the Vina division. Methods: A total of 193 water samples were collected from unprotected boreholes, unprotected wells and unprotected clay pots and analyzed physico-chemically including $\mathrm{pH}$, turbidity, total dissolved solid, conductivity and microbiologically such as enumeration of Enterococcus sp., Escherichia coli, Salmonella sp. and Vibrio sp using standard methods. This study revealed that safe status of the groundwater sources in the Vina division is very poor, considering the high levels of E.coli, Enterococcus sp. and the presence of enter pathogens microorganism such as Vibrio sp., Salmonella sp. and Shigella sp. Representative isolates (26) based on biochemical profile were selected for antibio resistance profile. All selected bacteria exhibited multiple antibiotic resistance at least for five antibiotics including ampicillin, amoxicillin + Clavulanic acid, amoxicillin, penicillin, erythromycin. Conclusion: This study suggests that drinking water available in Vina division of Cameroon lead to a substantial risk to public health. It is therefore necessary to developed strategies for protection of areas around drinking water supplies site. Further studies are therefore needed to assess the prevalence of water borne diseases in Vina division.
\end{abstract}

Keywords: Water Quality, Bacteriological, Physico-chemical, Antibiotic, Rural Communities, Vina

\section{Introduction}

Water availability has always been of great importance for human beings [1]. Recently, the United Nations stated that safe and clean drinking water is a human right [2]. In 2015, about 2.1 billion people lacked access to safely managed drinking water services and more than 1.8 billion people consume drinking water from a contaminated source [3, 4]. Rural communities in sub-Saharan Africa account for more than $50 \%$ of those lacking potable water $[5,6]$. Most of these communities, therefore rely on unimproved drinking-water supply sources such as springs, boreholes, wells, and rivers to meet fundamental needs such as drinking, sanitation, and cooking and for their sustainable development [4, 6-9]. These unimproved sources are mainly polluted by prevailing environmental factors, human activities and microbial pathogens originating from the intestinal tract of humans. [10] Microbial pathogens such as Vibrio cholerae, Shigella, Salmonella, Campylobacter jejuni, Klebsiella, which 
contribute significantly to the global burden of disease, as a result of water borne and water-related infectious diseases [9, 11-13].

Both local epidemiological survey and laboratory analysis of faecal bacteria in drinking water such as wells, boreholes, springs are recommended to ensure informative updates on the quality of water, build-up effective management strategies to improve the quality of water from these sources and to reduce the long-term impact of water-related diseases in developing countries [3, 14]. Faecal indicator bacteria (FIB) are commonly used to assess the hygienic safety of drinking waters. The presence of these bacteria indicates the possible presence of pathogens of faecal origin [4, 14]. Faecal coliforms (FC), Enterococcus sp (ENT) and E. coliare currently recognized by the WHO and the Joint Monitoring Programme (JMP) for Water Supply and Sanitation as the best FIB for monitoring faecal contamination of drinking water [2, 4, 15]. In several developing countries, other pathogens bacteria including Salmonella, $V$. cholera etc. need to be considered because of their negative health effect $[3,11$, 16]. In addition, they have been reported to exhibited resistance to several antibiotics [9, 17-19].

In Cameroon, the rate of access to drinking water hardly reaches $32 \%$. [20] The distribution of drinking water in urban areas is carried out by the Cameroon Water Utilities Corporation, while some non-governmental organizations supply the rural population. Some studies were done in the few regions of country and results shows that water quality is very poor [20-23]. The Adamawa region like other regions encounters enormous difficulties of access to drinking water and the unimproved/unclassified drinking-water sources supplies are the most recurrent. The contamination of drinking water varies considerably with the geographical zones, water-source and sanitation systems [14]. The aim of the present study was to assess the physicochemical and bacteriological quality of drinking water consume in the Vina division, Adamawa, Cameroon.

\section{Materials and Methods}

\subsection{Culture Media and Chemical Reagents}

The culture media Thiosulfate Citrate Bile Saccharose agar, Salmonella-Shigella Agar, Mc Conkey agar, Bile Azide Esculin agar, citrate Simmons, triple sugar Iron, Mueller Hinton agar were purchased from Scharlau (Scharlab, S. L. Barcelona, Spain). The antibiotics: Amoxicillin, Amoxicillin+Clavulanic acid, Penicillin G, Ampicillin, Chloramphenicol, Tetracycline, Streptomycin, Erythromycin, trimethoprim/sulphamethazol and ciprofloxacin were obtained from Biorad (Biorad, Marnes-la-Coquette, France). All other reagents used were of analytical grade.

\subsection{Characteristics of the Study Area and Sampling}

The study was conducted in 4 subdivisions (Ngaoundere I, Ngaoundere II Ngaoundere III and Mbe) of the Vina division (Adamawa, Cameroon). This region is one of the less populated regions of the country with 884,289 inhabitants in 2018. The climate is temperate and its savannah vegetation is situated in a hilly area. The region is under the influence of both a dry season (November-April) and a rainy season (May-October). The sub-urban zone of the region gets its drinking water from piped networked water supply, but the system has poor water quality/quantity because of intermittent water supply and low pressures in the piped water systems. On other hand, water from various sources such as the boreholes, wells, and rivers, and lakes are widely used by population. The Vina division have been selected in this study because of the frequent and persistent outbreaks of waterborne diseases these three past decades such as cholera epidemic (from 2004 and 2013 with 205 cases and 19 deaths), salmonellosis, and others gastro-enteric diseases [24]. The study was cross-sectional and conducted from August to October 2019. Samples $(n=193)$ were randomly collected from the 3-24th August, 2019 in 16 selected localities of 4 administrative subdivisions of Vina division. Five hundred millimeter of water were collected in sterile plastic containers and were taken to the laboratory for analysis within $6 \mathrm{~h}$. The set of water samples taken were samples from unimproved drinking water supply sources such as wells, boreholes (hand-pump), open reservoir like clay pots as well as mentioned in Figure 1.
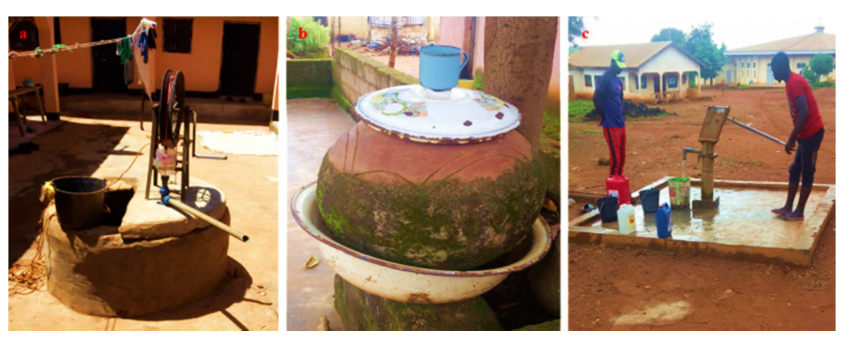

Figure 1. Drinking-water supplies sources unprotected/traditional well (a); clays pots water (b) hand pumps/boreholes (c).

\subsection{Physicochemical Analyses of Samples}

The physicochemical parameters including $\mathrm{pH}$, temperature, turbidity, electrical conductivity, and total dissolved solids (TDS) were measured for all samples using standard methodologies [25]. The $\mathrm{pH}$ was measured with $\mathrm{pH}$ Meter Model 370 (Jenway, U.K). The temperature was measured on the site of sampling by dipping a standard thermometer inside water for few minutes. Turbidity of samples was measured by $\mathrm{Hach}^{\circledR}$ 2100Q Handheld Turbidity meter. The electrical conductivity (EC) of water and the total dissolved solids (TDS) sample were measured by using Jenway Conductivity/TDS meter.

\subsection{Bacteriological Analysis}

Enumeration and isolation was done using the standard method as described by APHA [25]. Briefly, $100 \mathrm{~mL}$ of water samples were filtered through cellulose membrane filter paper of $0.45 \mu \mathrm{m}$ pore size (cellulose acetate, $\varnothing=0.45 \mu \mathrm{m}$ Sartorius) and were transferred to the Petri dishes containing the appropriate media for the culture. The media thiosulfate 
citrate bile saccharose agar, Salmonella-Shigella, McConkey agar and Bile Aesculinagarwere used for the enumeration of Vibrio sp., Salmonella, Shigella, E. coli (EC), Enterobacteriaceae, fecal coliforms (FC) and Enterococcus sp. (ENT) respectively. The plates were incubated at $45^{\circ} \mathrm{C}$ and $37^{\circ} \mathrm{C}$ for $24-48 \mathrm{~h}$ respectively for the thermotolerant bacteria (EC, FC and ENT) and other bacteria (Vibrio, Salmonella, Shigella). For negative controls, 100 mLof sterile distilled water, were processed after everytwentieth sample to ensure that the equipmenthad been adequately sanitized. For the isolation of entero-pathogens, samples were inoculated on appropriatemediadescribed previously. Samples were also inoculated into selenite-cystine broth to improve the isolation of Salmonella before their isolation. All inoculated media were incubated $a t 37^{\circ} \mathrm{C}$ for $24 \mathrm{~h}$. For each Petri dish and for each sample, a representative's colonies were randomly selected for their identification. Individual colonies were streaked twice on nutrient agar and characterized through phenotypical tests: colony shape and color, Gram staining, growth at different temperatures and $\mathrm{NaCl}$ concentrations, catalase, oxidase, citrate utilization according to Bergey's Manual of Determinative Bacteriology. The API 20 E (BioMérieux SA, France) gallery were used according to the manufacturer's instructions. The specificity of these gallery was at least $92 \%$. The results were recorded and the identification process was performed with Apident 2.0 (BioMérieux, France). Identity of isolates was confirmed using online API web services (https://apiweb.biomerieux.com).

\subsection{Susceptibility of Selected Bacteria to Antibiotics}

The susceptibility to antibiotics of each isolates was assessed using the standard disc diffusion method described by the European Committee on Antimicrobial Susceptibility Testing. [26] One hundred microliter of bacterial inoculum $(\approx$ $10^{8} \mathrm{CFU} / \mathrm{mL}$ ) adjusted to $0.5 \mathrm{McF}$ arland standard was spread on solidified Mueller Hinton agar plate followed by application of antibiotic discs using disc dispenser (HiMedia, India). The inoculated Petri dishes were then incubated at $37^{\circ} \mathrm{C}$ for $24 \mathrm{hrs}$. The following antimicrobials (Sigma Chemical Co., St. Louis, Mo.) classified according to their site of action were tested in the concentration $(\mu \mathrm{g})$ given in brackets: inhibitors of cell wall synthesis: Amoxicillin: 30; Amoxicillin + Clavulanic acid (20/10); Penicillin G (5); Ampicillin (10) inhibitor of protein synthesis: Chloramphenicol (30), Tetracycline (30); Streptomycin (500); Erythromycin (15); inhibitors of the synthesis of folic acid: trimethoprim/sulphamethazole (30) and inhibitors of DNA replication/transcription: ciprofloxacin (5). The inhibition zonewas measured using ruled template (HiMedia, India), andthe isolates were classified as sensitive/resistant in accordance with performance standards for antimicrobial disksusceptibility tests recommended by European Committee on Antimicrobial Susceptibility Testing. [26] The experiments wereperformed in triplicate, and average values were consideredfor patterns of antibiotic resistance or sensitivity.

\subsection{Statistical Analysis}

All water sample analyses were carried out in triplicate for each set of conditions. The results of microbial analysis were expressed as colony forming units (CFU) per $100 \mathrm{~mL}$ of water (CFU. $100 \mathrm{~mL}^{-1}$ ). Physico-chemical data were subjected to analysis of variance, differences between means were tested using the Duncan Multiple Range test; Pearson Correlation test to investigate possible relationship was already performed. Principal Component Analysis to classify the level of risk (according to WHO guideline classification) for each drinking water sources and the geographical zone. All statistical analysis was done using XLStat $^{\mathrm{TM}}$ v. 2016.02 software (Addinsoft, France). Effect of the factors and differences between means were considered significant at $\mathrm{P}<0.05$ level.

\section{Results}

\subsection{Physicochemical Properties of Different Water}

A total of 193 (117 boreholes, 19 of clay pots and 57 of traditional wells) samples of drinking waters from unimproved sources were collected in the areas of Mbe (18), Ngaoundere I (31), Ngaoundere II (74) and Ngaoundere III (70). These results showed that boreholes arethe main sources of drinking water (Figure 2a) particularly in the Ngaoundere subdivisions (Figure $2 \mathrm{~b}$ ). The temperature, conductivity and $\mathrm{pH}$ values of the freshly collected water samples were ranged from 22.9 to $24.8^{\circ} \mathrm{C}, 167$ to $438 \mu \mathrm{S} / \mathrm{cm}, 5.3$ to 6.8 respectively (Table 1$)$. The high value of conductivity was obtained from Ngaoundere I, II and III (up to $250 \mu \mathrm{S} / \mathrm{cm})$ while the low one from Mbe $(167 \mu \mathrm{S} / \mathrm{cm})$. There was no significant difference $(\mathrm{P}>0.05)$ of $\mathrm{pH}$ with the locality and the waters sources. The data obtained from temperature, conductivity and $\mathrm{pH}$ values were acceptable according to the WHO recommendations [2]. The turbidity values of the waters (range from 1 to $12 \mathrm{NTU})$ were upper than the references $(<1 \mathrm{NTU})$ while, the TDS values (range from $9-24 \mathrm{mg} / \mathrm{L}$ ) were less than the references $(500-1500 \mathrm{mg} / \mathrm{L}$ respectively). Similarly, there were no significant difference $(\mathrm{P}>0.05)$ of turbidity with the locality and the waters sources. In contrast, we observed a significance difference of TDS value with the sources of water $(\mathrm{P}<0.005)$. The correlation test (Pearson) showed the positive correlation between turbidity and TDS, traditional well; negative correlation with turbidity and clay pots $(\mathrm{r}=0.6 ; \mathrm{r}=0,5 ; \mathrm{r}=-0.76$ respectively). There was always negative correlation between $\mathrm{pH}$ and Ngaoundere II, boreholes $(\mathrm{r}=-0.41 ; \mathrm{r}=-0.64)$.

\subsection{Microbial Properties}

The municipal drinking water samples $(n=193)$ collected in this study were also examined for bacteriology, and microorganisms were detected in all samples. Consequently, all samples were positive to total and faecal coliforms, Enterococcus sp., Salmonella sp. And Shigella sp. Excepted Vibrio sp on which, $23.3 \%$ were free from contaminated. Moreover, all water samples were most contaminated with TC $\left(1.5 \times 10^{5}-2.1 \times 10^{6} \mathrm{CFU} / 100 \mathrm{~mL}\right)$ followed by FC $\left(1.2 \times 10^{3}-2.1 \times 10^{4} \mathrm{cfu} / 100 \mathrm{~mL}\right)$ and Enterococcus 
sp., Salmonella and Shigella, Vibrio sp. There was no significant difference of the contamination with the geographical area, drinking water supply sources. However, the levels of faecal contamination, based on the concentrations of the faecal indicator organisms, vary markedly with the samples analysed. The most contaminated municipalities were Ngaoundere I, III and Mbe. Similarly, the overall bacterial results were found the least in boreholes, and the highest results were in traditional wells and clay pots water.

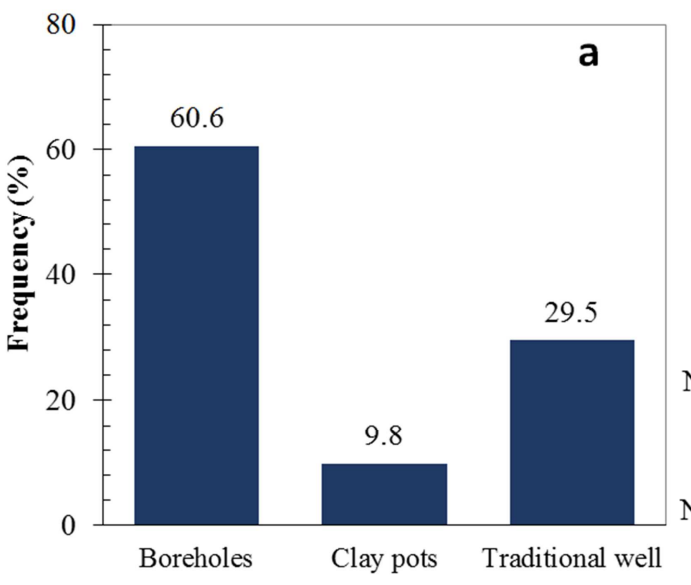

Water sources supply

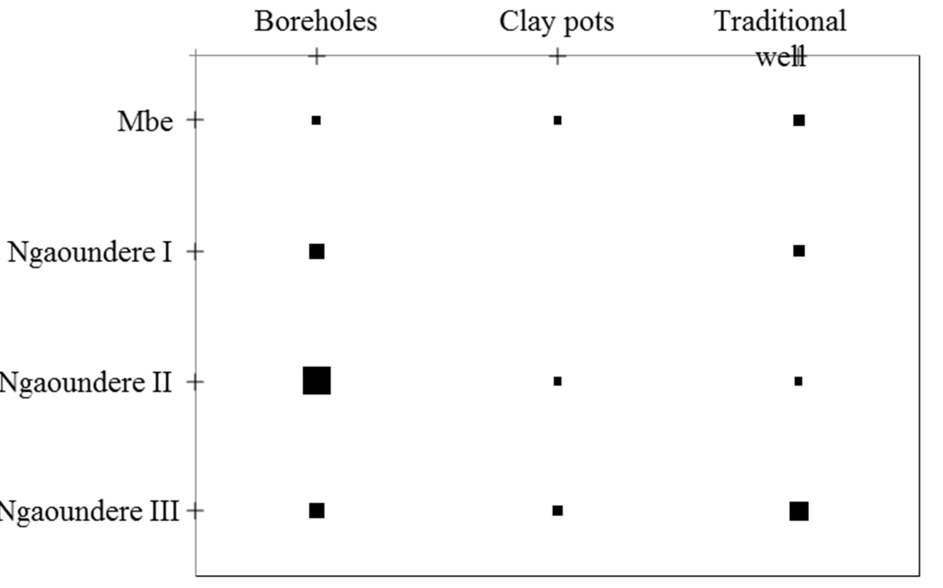

Drinking-water supply sources

Figure 2. Repartition of different of drinking-water supply sources (a) with the differents subdivisions (b).

Table 1. Ph, Turbidity and suspended solid values drinking-water samples ( $n=193)$.

\begin{tabular}{llllll}
\hline Modalities & Temperature $\left({ }^{\circ} \mathbf{C}\right)$ & Conductivity $(\boldsymbol{\mu S} / \mathbf{c m})$ & $\mathbf{p H}$ & Turbidity $(\mathbf{N T U})$ & TDS $(\mathbf{m g} / \mathbf{L})$ \\
\hline Mbe $(18)$ & $24.3 \pm 0.2$ & $256 \pm 3$ & $6.12 \pm 0.72^{a}$ & $5.05 \pm 3.94^{a}$ & $13.8 \pm 4.6^{a}$ \\
Ngaoundere I (n=31) & $23.1 \pm 0.2$ & $438 \pm 6$ & $5.96 \pm 0.49^{a}$ & $3.65 \pm 3.34^{a}$ & $15.3 \pm 5.1^{a}$ \\
Ngaoundere II (n=74) & $22.9 \pm 0.3$ & $351 \pm 4$ & $6.21 \pm 0.10^{a}$ & $2.10 \pm 1.02^{a}$ & $14.2 \pm 3.5^{a}$ \\
Ngaoundere III (n=70) & $23.7 \pm 0.2$ & $167 \pm 3$ & $6.08 \pm 0.28^{a}$ & $3.57 \pm 1.90^{a}$ & $14.0 \pm 2.9^{a}$ \\
Boreholes ( $\mathrm{n}=117)$ & $24.2 \pm 0.2$ & $416 \pm 6$ & $5.89 \pm 0.54^{a}$ & $5.47 \pm 1.60^{a}$ & $14.5 \pm 4.7^{a b}$ \\
Clay pots (n=19) & $23.6 \pm 0.3$ & $239 \pm 3$ & $6.05 \pm 0.79^{a}$ & $3.96 \pm 1.50^{a}$ & $10.7 \pm 1.0^{a}$ \\
Traditional well (57) & $24.8 \pm 0.1$ & $379 \pm 4$ & $6.26 \pm 0.51^{a}$ & $6.62 \pm 4.80^{a}$ & $17.8 \pm 5.0^{b}$ \\
References & $<25$ & $<1200$ & $6.5-8.5$ & $<1$ & $500-1500$ \\
\hline
\end{tabular}

The reference is based on the WHO guidelines [2]; NTU: Nephelometric turbidity unit; TDS: Total dissolved solids; Different superscripts in the same column indicate significant differences $(\mathrm{P}<0.05)$

Table 2. Microbial loads in different water samples.

\begin{tabular}{|c|c|c|c|c|c|c|}
\hline \multicolumn{7}{|c|}{ Microbial loads (CFU/100mL) } \\
\hline Modalities & $\mathbf{T C}^{a}$ & $\mathbf{F C}^{a b}$ & $\mathbf{E N T}^{a}$ & E. coli $^{a}$ & Salmonella sp. ${ }^{a}$ & Vibriosp. ${ }^{a}$ \\
\hline \multicolumn{7}{|c|}{ Geographical site } \\
\hline & $(4.5 \pm 2.9) \times 10^{5}$ & $(9.4 \pm 4.8) \times 10^{3}$ & $(3.9 \pm 3.0) \times 10^{2}$ & $(3.9 \pm 3.0) \times 10^{2}$ & $(2.0 \pm 1.7) \times 10^{2}$ & $(2.3 \pm 1.6) \times 10^{2}$ \\
\hline Mbe (18) & $1.5 \times 10^{5}-7.6 \times 10^{5}$ & $4.6 \times 10^{3}-1.4 \times 10^{4}$ & $22-5.7 \times 10^{2}$ & $22-5.7 \times 10^{2}$ & $23-3.1 \times 10^{2}$ & $0-3.3 \times 10^{2}$ \\
\hline Ngaoundere I & $(8.5 \pm 3.7) \times 10^{5}$ & $(8.6 \pm 3.4) \times 10^{3}$ & $(3.3 \pm 2.5) \times 10^{2}$ & $(3.3 \pm 2.5) \times 10^{2}$ & $(1.4 \pm 1.1) \times 10^{2}$ & $(2.2 \pm 1.6) \times 10^{2}$ \\
\hline$(n=31)$ & $4.7 \times 10^{5}-1.2 \times 10^{6}$ & $5.2 \times 10^{3}-1.1 \times 10^{4}$ & $13-4.8 \times 10^{2}$ & $13-4.8 \times 10^{2}$ & $9-2.1 \times 10^{2}$ & $10-3.8 \times 10^{2}$ \\
\hline Ngaoundere & $(9.2 \pm 1.8) \times 10^{5}$ & $(5.1 \pm 2.6) \times 10^{3}$ & $(3.5 \pm 2.7) \times 10^{2}$ & $(3.5 \pm 2.7) \times 10^{2}$ & $(3.1 \pm 2.3) \times 10^{2}$ & $(3.3 \pm 2.3) \times 10^{2}$ \\
\hline II $(n=74)$ & $7.6 \times 10^{5}-1.2 \times 10^{6}$ & $3.4 \times 10^{3}-7.9 \times 10^{3}$ & $17-5.1 \times 10^{2}$ & $17-5.1 \times 10^{2}$ & $12-4.5 \times 10^{2}$ & $0-4.7 \times 10^{2}$ \\
\hline Ngaoundere & $(6.2 \pm 4.1) \times 10^{5}$ & $(3.3 \pm 2.1) \times 10^{3}$ & $(4.1 \pm 3.3) \times 10^{2}$ & $(4.1 \pm 3.3) \times 10^{2}$ & $(3.8 \pm 3.0) \times 10^{2}$ & $(3.2 \pm 2.2) \times 10^{2}$ \\
\hline III $(n=70)$ & $2.2 \times 10^{5}-9.8 \times 10^{5}$ & $1.2 \times 10^{3}-5.7 \times 10^{3}$ & $45-6.1 \times 10^{2}$ & $45-6.1 \times 10^{2}$ & $(1.7-6.0) \times 10^{2}$ & $0-4.5 \times 10^{2}$ \\
\hline \multicolumn{7}{|c|}{ Drinking water sources } \\
\hline Boreholes & $(9.3 \pm 3.3) \times 10^{5}$ & $(9.3 \pm 4.7) \times 10^{3}$ & $(4.3 \pm 3.2) \times 10^{2}$ & $(4.3 \pm 3.2) \times 10^{2}$ & $(3.0 \pm 2.7) \times 10^{2}$ & $(2.0 \pm 1.4) \times 10^{2}$ \\
\hline$(\mathrm{n}=117)$ & $6.2 \times 10^{5}-2.1 \times 10^{6}$ & $4.6 \times 10^{3}-2.1 \times 10^{4}$ & $12-6.2 \times 10^{2}$ & $12-6.2 \times 10^{2}$ & $38-5.7 \times 10^{2}$ & $0-2.8 \times 10^{2}$ \\
\hline Clay pots & $(7.3 \pm 1.5) \times 10^{5}$ & $(6.2 \pm 4.1) \times 10^{3}$ & $(5.4 \pm 4.2) \times 10^{2}$ & $(5.4 \pm 4.2) \times 10^{2}$ & $(2.9 \pm 2.6) \times 10^{2}$ & $(4.2 \pm 3.0) \times 10^{2}$ \\
\hline$(n=19)$ & $5.7 \times 10^{5}-9.1 \times 10^{5}$ & $2.3 \times 10^{3}-9.7 \times 10^{3}$ & $33-8.1 \times 10^{2}$ & $33-8.1 \times 10^{2}$ & $69-4.8 \times 10^{2}$ & $0-5.9 \times 10^{2}$ \\
\hline Traditional & $(5.1 \pm 2.7) \times 10^{5}$ & $(3.9 \pm 1.7) \times 10^{3}$ & $(6.5 \pm 5.3) \times 10^{2}$ & $(6.5 \pm 5.3) \times 10^{2}$ & $(2.6 \pm 2.3) \times 10^{2}$ & $(4.9 \pm 3.5) \times 10^{2}$ \\
\hline well (57) & $3.8 \times 10^{5}-7.9 \times 10^{5}$ & $2.4 \times 10^{3}-5.8 \times 10^{3}$ & $69-9.8 \times 10^{2}$ & $69-9.8 \times 10^{2}$ & $81-4.1 \times 10^{2}$ & $0-7.0 \times 10^{2}$ \\
\hline References & 0 & 0 & 0 & 0 & 0 & 0 \\
\hline
\end{tabular}

$\mathrm{X} \pm \mathrm{SD}$ : means \pm standard deviation; $\mathrm{m}$ and $\mathrm{M}$ : minimum and maximum total count for each germ; TC: Total coliforms; FC: Faecal coliforms; ENT:

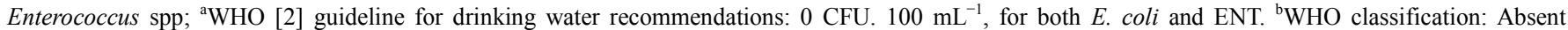
(conformity), 0-10 (low risk), 11-100 (intermediate) and $<100$ (high risk). 


\subsection{Biochemical Characterization}

Twenty-six isolates retained were identified (Table 3) and comprised different species belonging to the genus Aeromonas, Citrobacter, Enterobacter, Escherichia, Klebsiella, Proteus sp., Pseudomonas sp., Salmonella sp., Serratia, Shigella sp., Vibrio sp.

\subsection{Resistance to Antibiotics}

The characterized species were assessed for their antibioresistance (Table 3). All the isolates were susceptible to ciprofloxacin (except E. aerogenes, K. pneumoneae), streptomycin (except C. freundii, Salmonella spp., Vibriosp1.), Chloramphenicol (except Salmonella spp., Vibrio sp1) and tetracycline (except Salmonella spp., Vibrio sp1, Shigellasp). In contrast, all of them were resistant to Ampicillin, Amoxicillin + Clavulanic acid, Amoxicillin, Penicillin, erythromycin and trimethoprim + sulphamethazole (except $C$. freundii, E. coli); These effective antibiotics are therefore indicated in the empiric treatment of diarrheal cases or water-borne diseases of bacterial etiology in Cameroon. In addition, all the FC isolates exhibited MAR at least for five antibiotics. Salmonella sp. exhibited the most MRA (9/10) followed by Vibrio sp1 (8/10) and E. Aerogenes (7/10).

Table 3. Antibioresistance of selected isolates.

\begin{tabular}{|c|c|c|c|c|c|c|c|c|c|c|c|}
\hline Species & Code & $\mathbf{A M}$ & AMC & $\mathbf{P}$ & $\mathbf{A X}$ & SXT & CIPRO & $\mathbf{E}$ & STR & $\mathrm{C}$ & TE \\
\hline A. hydrophila (2) & S1TDr1, S1TBo1 & $\mathrm{R}$ & $\mathrm{R}$ & $\mathrm{R}$ & $\mathrm{R}$ & $\mathrm{R}$ & $\mathrm{S}$ & $\mathrm{R}$ & $\mathrm{S}$ & $\mathrm{S}$ & $\mathrm{S}$ \\
\hline C. freundii (1) & $\mathrm{S} 2 \mathrm{CBo} 2$ & $\mathrm{R}$ & $\mathrm{R}$ & $\mathrm{R}$ & $\mathrm{R}$ & $\mathrm{S}$ & $\mathrm{S}$ & $\mathrm{R}$ & $\mathrm{R}$ & $\mathrm{S}$ & $\mathrm{S}$ \\
\hline E. aerogenes (2) & S1SBo1, S1SBo2 & $\mathrm{R}$ & $\mathrm{R}$ & $\mathrm{R}$ & $\mathrm{R}$ & $\mathrm{R}$ & $\mathrm{R}$ & $\mathrm{R}$ & $\mathrm{S}$ & $\mathrm{S}$ & $\mathrm{S}$ \\
\hline E. $\operatorname{coli}(3)$ & $\mathrm{S} 3 \mathrm{CTr} 1, \mathrm{~S} 3 \mathrm{CTr} 2, \mathrm{~S} 3 \mathrm{CTr} 3$ & $\mathrm{R}$ & $\mathrm{R}$ & $\mathrm{R}$ & $\mathrm{S}$ & $\mathrm{S}$ & $\mathrm{S}$ & $\mathrm{R}$ & $\mathrm{S}$ & $\mathrm{S}$ & $\mathrm{S}$ \\
\hline K. pneumoneae (3) & S1TDr2, S1CBo2, S1CBo1 & $\mathrm{R}$ & $\mathrm{R}$ & $\mathrm{R}$ & $\mathrm{R}$ & $\mathrm{R}$ & $\mathrm{R}$ & $\mathrm{R}$ & $\mathrm{S}$ & $\mathrm{S}$ & $\mathrm{S}$ \\
\hline Proteus spp. (3) & S1SDr1, S2SBo2, S1SBo3 & $\mathrm{R}$ & $\mathrm{R}$ & $\mathrm{R}$ & $\mathrm{R}$ & $\mathrm{R}$ & $\mathrm{S}$ & $\mathrm{R}$ & $\mathrm{S}$ & $\mathrm{S}$ & $\mathrm{S}$ \\
\hline Pseudomonas spp. (3) & $\mathrm{S} 1 \mathrm{CB}$ 3, S2TDr1, S2CBo1 & $\mathrm{R}$ & $\mathrm{R}$ & $\mathrm{R}$ & $\mathrm{R}$ & $\mathrm{R}$ & $\mathrm{S}$ & $\mathrm{R}$ & $\mathrm{S}$ & $\mathrm{S}$ & $\mathrm{S}$ \\
\hline Salmonella spp. (2) & $\mathrm{S} 3 \mathrm{STr} 3, \mathrm{~S} 3 \mathrm{~S} \operatorname{Tr} 2$ & $\mathrm{R}$ & $\mathrm{R}$ & $\mathrm{R}$ & $\mathrm{R}$ & $\mathrm{R}$ & $\mathrm{S}$ & $\mathrm{R}$ & $\mathrm{R}$ & $\mathrm{R}$ & $\mathrm{R}$ \\
\hline S. marcescens (2) & S2CBo3, S3STr1 & $\mathrm{R}$ & $\mathrm{R}$ & $\mathrm{R}$ & $\mathrm{R}$ & $\mathrm{R}$ & $\mathrm{S}$ & $\mathrm{R}$ & $\mathrm{S}$ & $\mathrm{S}$ & $\mathrm{S}$ \\
\hline Shigella sp (2) & S2SBo1, S3STr2 & $\mathrm{R}$ & $\mathrm{R}$ & $\mathrm{R}$ & $\mathrm{S}$ & $\mathrm{R}$ & $\mathrm{S}$ & $\mathrm{R}$ & $\mathrm{S}$ & $\mathrm{S}$ & $\mathrm{R}$ \\
\hline Vibrio $\mathrm{sp} 2$. (2) & S3TTr1, S3STr1 & $\mathrm{R}$ & $\mathrm{R}$ & $\mathrm{R}$ & $\mathrm{R}$ & $\mathrm{R}$ & $\mathrm{S}$ & $\mathrm{R}$ & $\mathrm{S}$ & $\mathrm{S}$ & $\mathrm{S}$ \\
\hline Vibrio sp1. (1) & S3TTr2 & $\mathrm{R}$ & $\mathrm{R}$ & $\mathrm{R}$ & $\mathrm{S}$ & $\mathrm{R}$ & $\mathrm{S}$ & $\mathrm{R}$ & $\mathrm{R}$ & $\mathrm{R}$ & $\mathrm{R}$ \\
\hline
\end{tabular}

A: Aeromonas; C: Citrobacter; E: Enterobacter and Escherichia; K: Klebsiella; S: Serratia; V: Vibrio; AM: Ampicillin; AMC: Amoxicillin + Clavulanicacid; CIP: Ciprofloxacin; AX: Amoxicillin; SXT: Sulphamethazol/Trimethoprim; E: Erythromycin; P: Penicillin G; STR: Streptomycin; C: Chloramphenicol; TE: Tetracyclin;

\section{Discussion}

\subsection{Physicochemical Properties of Water}

Rural and sub-rural communities in the Adamawa region of Cameroon are known to rely on unclassified water sources such as hand-dugs wells and boreholes, which are used by population as drinking water sources supplies. Preliminary tests (data non shown) illustrated that the majority of the drinking water sources harbored enteropathogens microorganisms. However, physico-chemical properties, updated data on microbial quality and antibio resistance profiles of bacterial isolates were not available. In this study, the physico-chemical parameters, microbial quality as well as antibiotic susceptibility profiles of water sources were assessed in order to establish the microbial safety of water sources and to provide data on antibio resistance profile of bacteria for better management of patients requiring antibiotic therapy.

Results revealed that the physico-chemical (temperature, $\mathrm{pH}$ and turbidity) quality was not acceptable, except for conductivity comparing to the value recommended by the WHO. [2] Some authors reported the low $\mathrm{pH}$ values and the high turbidity values of grounder and surfaces water sources such as wells, boreholes, fountains, river $[9,10]$. The temperature, $\mathrm{pH}$ and turbidity value respectively vary with the intensity of the sunlight during the sampling, buffering capacity $\left(\mathrm{CO}_{2} /\right.$ bicarbonate/carbonate equilibrium $)$ of the water, suspended particulate matter in the water [10]. The generally low $\mathrm{pH}$ values obtained in the grounder water might be due to the high levels of free $\mathrm{CO}_{2}$, which may be due to the presence of organotrophic microorganisms like fungal and coliforms [10]. According to turbidity, the level in raw water is less than $1.0 \mathrm{NTU}[2,9]$. Turbidity readings may vary between water sources due to water colour, suspended particle size, particle composition whereas, TDS expresses the organic level of pollution of water [20].

\subsection{Microbial Properties}

Microbiological analyses clearly show that the studied wells and boreholes are significantly polluted with by FIB (more than $10^{2}$ CFU.mL ${ }^{-1}$ ). This could be due to the contamination of groundwater, particularly the discharge of domestic waste by population's riverside, disposal of faeces from human or animal origin and waste dumps which significantly affect the bacterial microflora in water runoff and drinking water supply points. Observations made on-site during sampling show that several others risk factors could be associated with these contamination rates. As for wells, contamination could be due to the presence of latrines or septic tanks within $25 \mathrm{~m}$ of the wells, uncontrolled construction of new wells without respecting health criteria and depth of sampled wells which varied between 5 and $20 \mathrm{~m}$ from the surface. This depth represents a major problem for 
the population because the water level of certain wells exceeds the surface during the rainy season. Likewise, this study was carried out during the month of August, which corresponds to the rainy season at the study area. Thus, continuous construction of latrines coupled with other inadequate sanitary practices lead to a strong accumulation of point sources. These may improve the multiplication of FIB and pathogenic microorganisms in the underground aquifers of the area.

The literature showed that raising the water table during the rainy season decreases the distance between the base of on-site sanitation systems and groundwater which facilitates the lateral transport of contaminants to wells and their propagation in the groundwater system. [27] The extraction of groundwater for various uses will facilitate the intake of contaminant from nearby sources of contamination. Concerning the boreholes in the Vina division, the majority have been provided by governments that apply standards in the siting of boreholes to reduce possible adverse impacts on the quality of water. This could explain the weak contamination as compared to the hand-dug wells observed in this study. Therefore, the high number of FIB observed in boreholes samples could be linked to the multiple contamination of the water table by faeces, discharge of surface water from latrines, non-maintenance of boreholes (i.e. old, insanitary pump seals...) and surrounding areas, non-compliance with hygienic rules. These results have been reported by several authors $[4,6]$. Lutterodt et al. [8] in Ghana showed that more than $75 \%$ of boreholes are at risk. Likewise, the non-significant difference observed between numbers of $E$. coli in water samples from wells and boreholes can be attributed to widespread groundwater pollution in the Adamawa region. Based on the WHO guidelines [2] for the absence of faecal coliforms, Enterococcus, E. Coli in $100 \mathrm{~mL}$ of drinking water, the grounder waters from the Vina locality is not suitable for human consumption. The similar result has been reported in the literature [3]. In addition, the results obtained in Figure 3 illustrated that all samples collected in study area represent a high risk for human health.

\section{Biplot (F1 et F2 : 95,02 \%)}

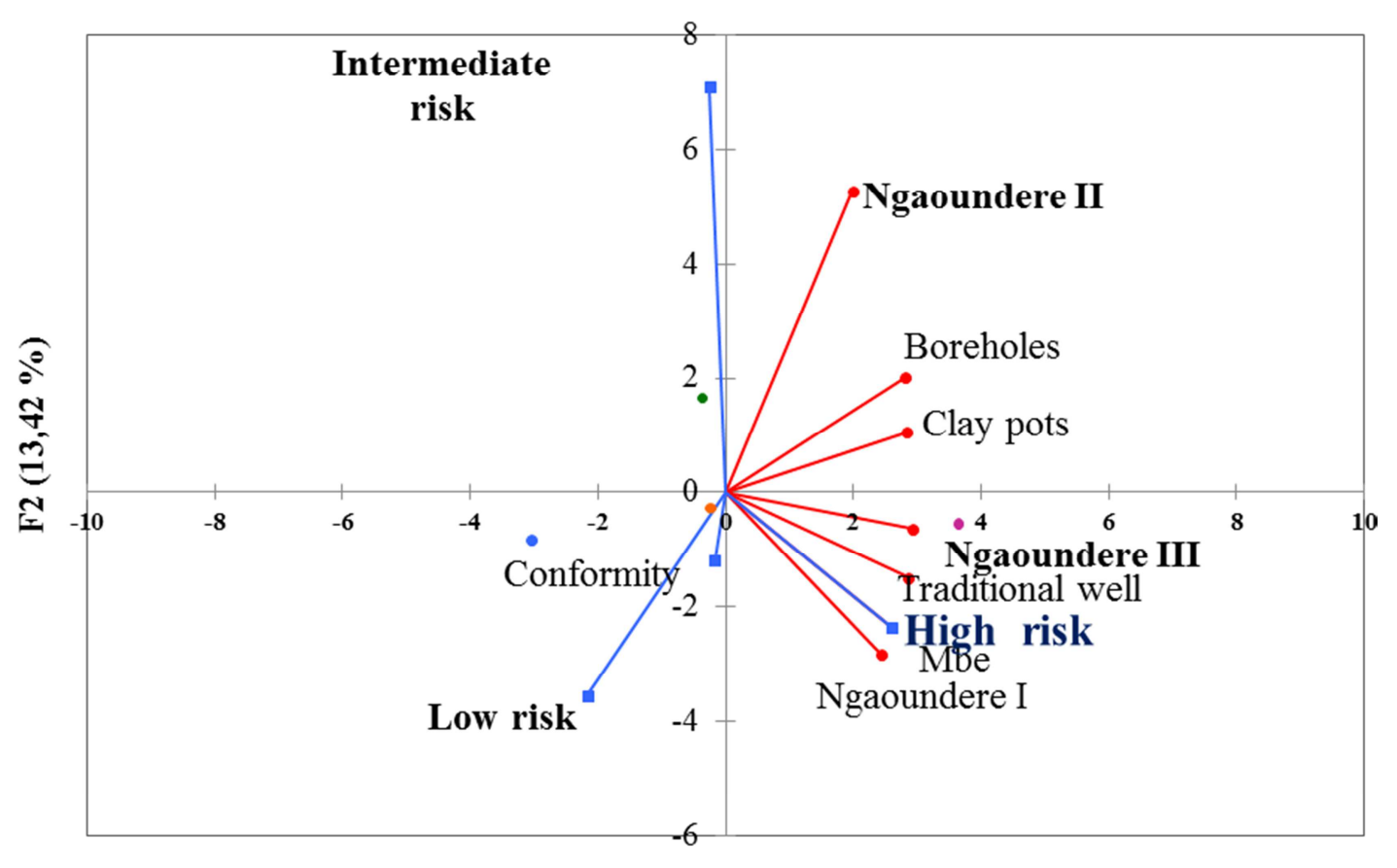

F1 $(81,61 \%)$

Figure 3. Distribution of localities, water sources supply and sanitary risk on the F1, F2 axis.

Nowadays, the major interest of public health authorities in improving the conditions for access to drinking water in rural areas is also focused on the identification and characterization of microorganisms associated to water-borne diseases which are considered to be indicators of microbiological parameters. Authors reported that the presence of FC and ENT could suggests the presence of enteric pathogens $[4,9,13]$. The consumption of water contaminated bywaterborne microorganisms can be a significant source of epidemics and the use of contaminated water for food purposes can also pose serious human threats
$[3,20]$.

\subsection{Biochemical Characterization}

The pathogens widely recognized to cause dangerous waterborne diseases including Salmonella typhi, Vibrio cholerae, Shigella and pathogenic E. coli have been identified in this study. Others authors reported the potential presence of other emerging pathogens microorganisms such as Pseudomonas, Aeromonas, Klebsiella, Acinetobacter, Flavobacterium, and Serratia which can spread disease to 
humans in drinking-water samples [3, 9, 10, 19]. These bacteria genera has been identified in this study. They are widely implicated in high prevalence of several emerging, nosocomial diseases and in the transfer of antibiotics resistances gene $[9,17,28]$. Their presence in drinking water may lead to health hazards such as diarrhoeal diseases, which are responsible for an important rate of morbidity and mortality in adults and children under 5 years old [16]. Management of diarrhoea may require the administration of antibiotics. However, several bacteria are well known to be resistant to a wide array of antibiotics [9]. In addition, the occurrence of MAR bacteria in the drinking water in the world has significantly increased [28, 29].

\subsection{Antibiotics Resistance}

Results on antibio resistance in this study showed that selected bacteria exhibited MAR at least for five antibiotics Ampicillin, Amoxicillin + Clavulanic acid, Amoxicillin, Penicillin, erythromycin. In addition, Salmonella sp. exhibited MRA with 4 others ATB: Sulphamethazol+ trimethoprim; streptomycin, chloramphenicol and tetracyclin) and E. aerogeneswith 3 others ATB: sulphamethazol+trimethoprim; ciprofloxacin. We noted the resistance of E. Aerogenes and $K$. Pneumoneae to Ciprofloxacin. MARrefer to resistance to two or more classes of antibiotics. The MAR of Salmonella, Shigella, Aeromonas and Pseudomonas, Citrobacter, Escherichia, Proteus, Serratia and Vibrio obtained in this study accordswith other findings [17, 28]. Similarly, resistance of Salmonella, $V$. cholerae to tetracycline, chloramphenicol and E. aerogenes, $K$. pneumoneae to Ciprofloxacin isolated from drinking water have been reported [9, 17, 19]. It should be noted that susceptibility of bacteria to antibiotics is not static with the time and resistance may be due to antibiotic abuse, antibiotic overuse or may be chromosomally or plasmid mediated [9]. Antibiotic usage must therefore be carefully regulated and monitored by prescriber. In this regards, Oluyege et al. [19] reported that complex socio economic and behavioural factors are associated with the selection and distribution of antibiotic resistance, particularly regarding diarrheal and commensal enteric pathogens indeveloping tropical countries. The same observation has been done in this study. For example, the low literacy levels of the populations, the poverty, the lack of medical structure and medical patricians. The consequences are self-medication, the purchase of antibiotics in the streets, non-compliance with therapeutic regimens.

\section{Conclusion}

The safe status of the groundwater sources in the rural andsub-rural area of Adamawa region is very poor, considering the high levels of coliforms, presence of enteropathogens microorganism and bacteria isolates exhibit multiple antibiotic resistance (MAR). These results highlight the potential human risks associated with the persistent waterborne diseases in the studied area including gastroenteritis disorders, typhoid fever and also, the difficulties on their clinical management. The absence of safely managed sanitation systems and services, combined with the lack of water resource protection, is therefore at least partially responsible for the contamination of water sources by human faeces, and for the occurrence of waterborne diseases in the neighbourhood. Data on water quality should be updated and controlled in order to minimize acute problem of water related diseases, which are endemic to the health of human being.

\section{Declaration of Interest Statement}

The authors declare that they have no competing interests.

\section{Acknowledgements}

We thank the University of Ngaoundere for their technical support.

\section{References}

[1] Pathak SP, Gopal K. Prevalence of bacterial contamination with antibiotic resistant and enterotoxigenic fecal coliforms in treated drinking water. J Toxicol Environ HealthPart A 2008; 71: $327-33$.

[2] WHO. Guidelines for drinking-water quality, 4th ed; Geneva, Switzerland: WHO, World Heal Organ 2011; 216: 303-304.

[3] KapemboML, Mohammed D, Salah M, Al Thevenon F, Laffite A, Bokolo MK, et al. Prevalence of water-related diseases and groundwater (drinking-water) contamination in the suburban municipality of Mont Ngafula, Kinshassa (Democratic Republic of the Congo). J Environ Sci Heal Part A2019; 54: 840-50.

[4] Kostyla R, Bain R, Cronk J Bartram. Seasonal variation of fecal contamination in drinking water sources in developing countries: A systematic review. Sci Total Environ 2015; 33343.

[5] OdonkorST. Escherichia coli as a tool for disease risk assessment of drinking water sources. Int J Microbiol 2020.

[6] Bain R, Cronk R, Hossain R, Bonjour S, Onda K, Wright J, et al. Global assessment of exposure to faecal contamination through drinking water based on a systematic review. Trop Med Int Heal 2014; 19: 917-27.

[7] Hussain T, Roohi A, Munir S, Ahmed I, Khan J, Kim KY, et al Biochemical characterization and identification of bacterial strains isolated from drinking water sources of Kohat, Pakistan. African J Microbiol Res 2013; 7: 1579-90.

[8] Lutterodt G, Van De Vossenberg J, Hoiting Y, Kamara AK, Oduro-kwarteng S, Foppen JWA. Microbial groundwater quality status of hand-dug wells and boreholes in the Dodowa area of Ghana. Int J Environ Res Public Health 2018; 15: 1-12.

[9] Obi CL, Bessong PO, Momba MNB, Potgieter N, Samie A, Igumbor EO. Profiles of antibiotic susceptibilities of bacterial isolates and physico-chemical quality of water supply in rural Venda communities, South Africa. Water SA 2004; 30: 515-20. 
[10] Omezuruike OI, Damilola AO, Adeola OT, Enobong A. Microbiological and physicochemical analysis of different water samples used for domestic purposes in Abeokuta and Ojota, Lagos State, Nigeria. African J Biotechnol 2008; 7: 617-21.

[11] WHO. Preventing diarrhoea through better water, sanitation and hygiene. World Heal. Organ. 2014; $1-48$.

[12] WHO/UNICEF, Joint Water Supply. Progress on drinking water and sanitation. 2014.

[13] WHO, "Guidelines for Drinking-water Quality. World Heal. Organ. 2006; 1 .

[14] Nienie AB, Sivalingam P, Laffite A, Ngelinkoto P, Otamonga J, Matand A, et al. Microbiological quality of water in a city with persistent and recurrent waterborne diseases under tropical sub-rural conditions: The case of Kikwit City, Democratic Republic of the Congo. Int J Hyg Environ Health 2017; $1-9$.

[15] Bain R, Wright JA, Bain R, Cronk R, Wright J, Yang H, et al. Fecal contamination of drinking-water in low- and middleincome countries: A systematic review and meta-analysis, PLoS, Med2014; 11: 1-23.

[16] WHO. World health statistics. Rep World Heal Organ, 2015.

[17] PatersonDL. Resistance in Gram-negative bacteria: Enterobacteriaceae. Am J Infect Control2006; 34: S20-S28.

[18] De Boeck H, Miwanda B, Lunguya-Metila O, MuyembeTamfum J J, Stobberingh E, Glupczynski Y, et al. ESBLpositive enterobacteria isolates in drinking water," Emerg Infect Dis 2012; 18: 1019-20.

[19] Oluyege JO, Dada AC, Odeyemi AT. Incidence of multiple antibiotic resistant Gram-negative bacteria isolated from surface and underground water sources in south western region of Nigeria, Water Sci Technol 2009; 59: 1929-36.
[20] Temgoua, E. Chemical and bacteriological analysis of drinking water from alternative sources in the Dschang municipality, Cameroon. J Environ Prot2011; 2: 620-28.

[21] AkoAA, TakemGE. Water quality and occurrence of waterborne diseases in the Douala 4th District, Cameroon. Water Sci Technol 2009; 59: 2321-29.

[22] Yongsi HBN. Suffering for water, suffering from water: Access to drinking-water and associated health risks in Cameroon. J Heal Popul Nutr 2010; 28: 424-35.

[23] Djuikom E, Njine T, Nola M, Sikati V, Jugnia L B. Microbiological water quality of the Mfoundi River watershed at Yaoundé, Cameroon, as inferred from indicator bacteria of fecal contamination," Environ Monit Assess 2006; 122: 17183 .

[24] Unicef, "Choléra epidémiologie et réponse factsheet cameroun," 2011.

[25] APHA. Standard methods for the examination of water and wastewater. Am Public Heal Assoc, 21st ed W, 2005.

[26] CASFM/EUCAST. Comité de l'antibiogramme de la société française de microbiologie. Eur Soc Clin Microbiol Infect Dis 2019; V1.0 2019: S3-4.

[27] Chuah, CJ, Ziegler, AD. Temporal variability of faecal contamination from on-site sanitation systems in the groundwater of northern Thailand. Environ Manage 2018; 61: 939-53.

[28] Zhang X, Zhang T, Fang HHP, Obi CL, Bessong P, Momba $\mathrm{MNB}$, et al. ESBL-positive enterobacteria isolates in drinking water. Emerg Infect Dis 2009; 18: 1019-20.

[29] Papandreou S, Pagonopoulou O, Vantarakis A,\& Papapetropoulou M. Multiantibiotic resistance of Gramnegative bacteria isolated from drinking water samples in southwest Greece," J Chemother 2000; 12: 267-73. 